\title{
Comparison of Strain Ellipsoid Shape in the South of Ardabil Range (NW), Based on the Results of the Magnetic Susceptibility Anisotropy and Paleostress Methods
}

\author{
Ramin Sadeghi ${ }^{*}$, Abdollah Saeedi², Mehran Arian1, Manochehr Ghorashi'2,3, Ali Solgi1 \\ ${ }^{1}$ Department of Geology, Science and Research Branch, Islamic Azad University, Tehran, Iran \\ ${ }^{2}$ Research Institute for Earth Sciences, Geological Survey, Tehran, Iran \\ ${ }^{3}$ Department of Geology, North Tehran Branch, Islamic Azad University, Tehran, Iran \\ Email: ${ }^{*}$ raminsadeghi54@gmail.com
}

Received 15 July 2015; accepted 18 September 2015; published 21 September 2015

Copyright (C) 2015 by authors and Scientific Research Publishing Inc.

This work is licensed under the Creative Commons Attribution International License (CC BY).

http://creativecommons.org/licenses/by/4.0/

(c) (i) Open Access

\begin{abstract}
In recent years, the method of magnetic survey as one of the new techniques in geological and geophysical studies is known. In this study to determine the shape of the stress field of the two methods, Anisotropy of Magnetic Susceptibility (AMS) and paleostress have been used. Paleomagnetism is the characteristics of magnetic rocks. Some issues in associated with the past places of continental and oceanic plates can be solved. AMS is one of the paleomagnetism methods that pay to measurement of parameters (which are reflector of the magnetic fabrics rocks). It is presenting an ellipsoid with three-axis perpendicular to each other that defines magnetic ellipsoid. In this regard, the number of 12 stations in different rocks (Jurassic to Quaternary) in the southern region of Ardebil sampling was conducted. In this connection, the study of magnetic fabrics has shown an elliptical magnetic susceptibility with the prolate shape. For the separation of paleostress phases in the Khalkhal area using the analysis of the paleostress based on the study of heterogeneous fault-slip data and sliding lineaments. Firstly, data were picked from 10 stations, and after their analysis, the elliptical shape (prolate) has been determinated. The shape of the ellipsoid, based on AMS and paleostress methods and their results show that in both methods the shape of the stress field is prolate.
\end{abstract}

\section{Keywords}

Paleostress, Anisotropy, Inversion Method, Strain Ellipsoid, Iran

\footnotetext{
${ }^{*}$ Corresponding author.
}

How to cite this paper: Sadeghi, R., Saeedi, A., Arian, M., Ghorashi, M. and Solgi, A. (2015) Comparison of Strain Ellipsoid Shape in the South of Ardabil Range (NW), Based on the Results of the Magnetic Susceptibility Anisotropy and Paleostress Methods. Open Journal of Geology, 5, 611-622. http://dx.doi.org/10.4236/ojg.2015.59054 


\section{Introduction}

Ardabil province has got different geological properties from the other parts of Azerbaijan region and Iran. The faults that are origin of the earthquakes in this area may be affected by rotation of the western Alborz. Therefore calculation of stress direction and estimation of stress field shape will be unrealistic. In this article by using the paleomagnetism and paleostress methods, some of the unknowns including dominant stress trend of the region, phase separation of the stress and strain ellipsoid have been prepared.

\subsection{Location}

The study area (Figure 1) is located in the southern range of Ardebil in the West Alborz Mountain. Alborz mountain belt with several thousand kilometers between the Caspian Sea and the Central Iran has situated. It is a part of the Alpine-Himalaya belt that located between Eurasian and Cimmerian plates.

Alborz Mountain is a result of the above collision since the late Triassic. Extensional phases in Alborz Orogeny in the study area have created a collection of volcanic rocks, including lava flows, and pyroclastic generally entitled Karaj formation.

Magmatism has been active in particular in Oligocene and Neogne and the injection of magma has been in the host rocks of Eocene rocks, especially in the domed shape with the composition of Rhyoliite and Dacite. Ardabil region is located in the bend of Alborz on the West Talesh Mountain, and based on structural and stratigraphic situations different from the other parts of Iran. It has been the more complex and the evidence of metamorphism in rocks is common.

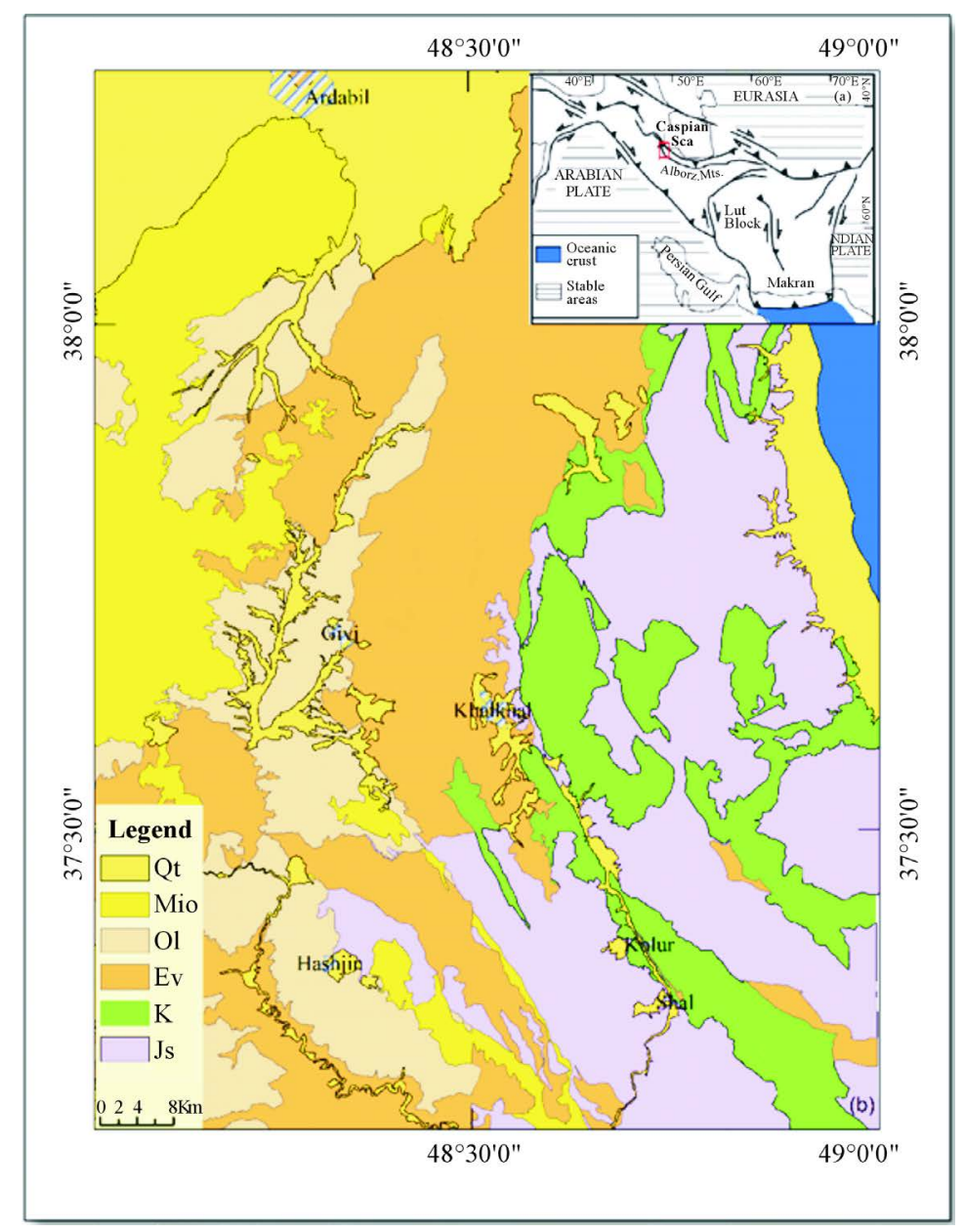

Figure 1. Schematic tectonic map of Iran (insert map) and schematic geological map of the Ardabil region. 


\subsection{Tectonic Setting}

The study area has located in West-Central Alborz-Lesser Caucasus physiographic province (Figure 1). Dominant structural trend in this province is NW-SE. From tectonics view, it contains deformed zone (fold and thrust belt) of Cimmerian miniplate that formed in northern active margin until late Triassic. Then it has rifted by tension in a back arc basin of Neotethyian subduction zone in the south margin of Cimmerian miniplate. Development of that rift stopped in the late Cretaceous and then, renewed in the Eocene by spreading in submarine arc basin of Neotethyian subduction zone. In other words, this hinterland is a result of a magmatic arc system spreading in the evolutional back arc basin. After that, West-Central Alborz and Lesser Caucasus hinterland has formed by deformation and regional uplift from SW part of Caspian Sea to Black Sea [1]-[3]. Based on previous works on the salt and mud diapirism [4]-[15] and neotectonic regime in Iran [16]-[21], Zagros in south Iran is the most active zone [22]-[42]. Then, Alborz [43]-[82] and Central Iran [83]-[98] have been situated in the next orders.

There is evidence of two young tectonic phases during Cenozoic in study area. The first phase in late Eocene in the posterior with compressional stress has been NE-SW trend and the second phase in the Middle Miocene (Sarmatin) compressional phase has been SE-NW trend that caused the evolution of the thrusts with N-S trend in this area. The tectonic events causing the Eocene to the Quaternary have been the formation of the current morphology of this part of the crust of Iran block. In this area structural trend has changed from Northwest-South East to the North-South. The tectonic evidence of the region shows that the west sector (West block) has been stretched in the mid Paleocene and after the collision with Arabian plate, a depression has created towards the Eastern block. This depression has located widely under the volcanic scrambling that formed the northern part of Azerbaijan. This scrambling volcanic-magmatic has been extremely high since the late Paleocene and throughout the early Eocene. Then, it has decreased in the Miocene and Oligocene and there was a big scrambling under the influence at the beginning of the Quaternary across the study area. Morphotectonic units of the study area can be separated and classified as following from North to South (Figure 2).

1) Moghan foreland basin as a portion of South Caspian-Black sea foreland basin.

2) Arasbaran, Qarah Dagh, Hashtchin, volcano-plutonic belt that imply to southward subduction [99].

3) Tectono-magamatic reactivated zones in Neocene (with oblique trend related to Paleogene volcano-plutonic arc) that formed the volcanoes (like the Sabalan) and uplifting intrusive doming (Qusheh Dagh).

4) Subsidence zone between the mountain and the volcanoes.

The tectonic units have been bounded by the main faults. These faults are Aras fault in the North, Tabriz fault in the West, Talysh and Astara fault system in eastern boundary, and also, magnetic lineament East Meyaneh in the South-East border and Bozquosh fault in the South (Figure 3).

\section{Material and Methods}

For studies of stress by examining the geological maps and satellite images and field operations 5 range which they fault and fracture surfaces are visible and were selected and measured data page was picked up fractures (Figure 4 and Figure 5). Then the data was processed and value and with the use of the software Fault Kin,

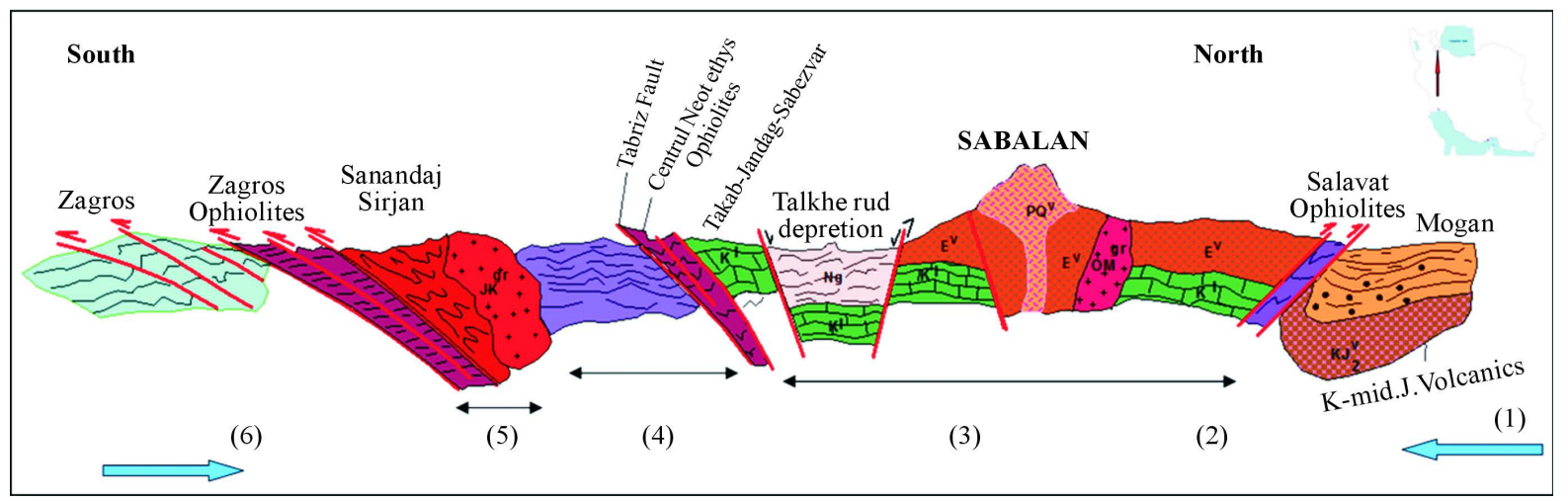

Figure 2. Schematic of the structural represents the main structural elements from the Zagros Mountains to the Caucasus can be seen in it study the area. 


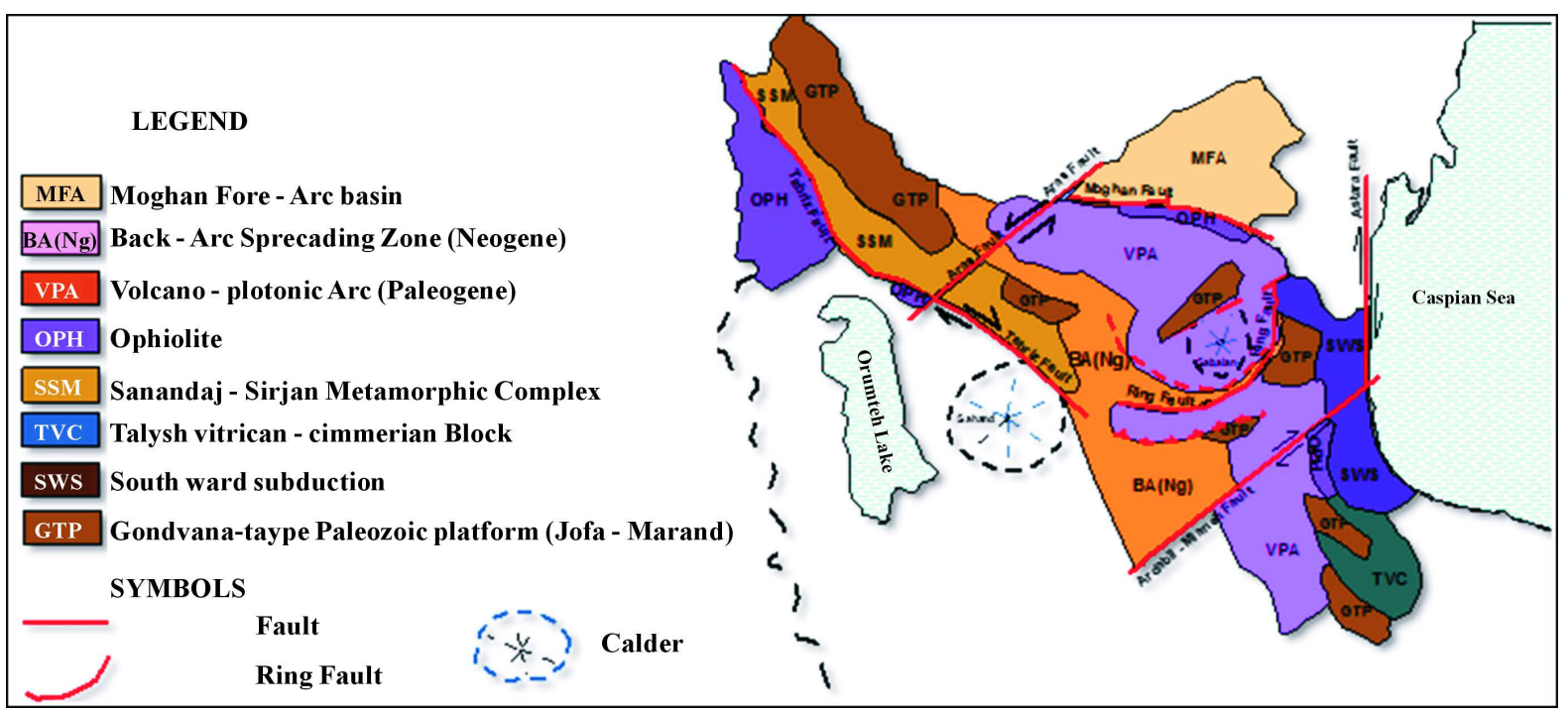

Figure 3. The structural map of the studied range and North West of Iran.

Tectonic FP data for import into software was ready for Win Tensor, and for each region were paleostress analysis [100].

After the regionalization study area in each range of data after processing with the use of the software was paid to the distinction between phases of stress Win Tensor that specifications relating to each phase in Table 1 is be the position of the main maximum stress $\sigma_{1}$ and $\sigma_{3}$ minimum tension each phase on the range of elliptical has been demarcated. Each pair of main stress perpendicular to the arrow tip, large and small shows each phases.

\section{Results and Discussion}

In the study area, from about 12 stations, in the longitude the range of $48^{\circ}$ to $49^{\circ}$ samples were that's part of the Talysh Mountains and Western Alborz belt (Figure 6). Stations in place of the Talysh Mountains turns bending in place rotate the belt West Alborz and changing trend of the structures of the North East to the South West of the South-North-South, South East and South West of Ardabil province are focused. Because of possible impact of the magnetic minerals on lands and changing the chemical composition or spin them in the vicinity of faults the choice of the sampling stations at a distance of at least of the main fault. Most stations (PS1, SP2, S1, S2, S3, S4) of the igneous units includes basalt up to andesite from the Eocene period of up to quaternary. And the number of stations of the unit stone includes marl shale, and sandstone (S6, PS3, SP3, S7, S3) was removed from any station 15 - 8 sample preparation and from sample of every sample was obtained manually (Table 2).

With the use of the software Anisoft 4.2, the magnetic parameters can determine the magnitude of anisotropy (Table 3), including the shape parameter or $\mathrm{T}$ that describes the magnetic elliptical shape parameter [101]-[111]. The value of this parameter in the range of between change the -1 to +1 the shape of the elliptical shape of the prolate to form a pancake (pancake elliptical) changed if T from 0 to 1 [112]. Magnetic elliptical shape would be prolate or have a smoker, in this case $\mathrm{K} 1>\mathrm{K} 2 \geq \mathrm{K} 3$.

If $\mathrm{T}$ is in the range between be 0 to +1 magnetic elliptical shape is Oblate and will be $\mathrm{K} 1 \geq \mathrm{K} 2>\mathrm{K} 3$. When $\mathrm{K} 1=\mathrm{K} 2=\mathrm{K} 3$ Magnetic elliptical shape will be the spherical.

Therefore we can be determined some samples of higher susceptibility that they have been rated the study on the range field shape or $\mathrm{T}$ Parameter a range of values shows for $-0 / 720$ to $-0 / 164$. According to Figure 7 more samples obtained from stations PS1, S2, S3, S4 and S5 the field shape shows $(0>\mathrm{T}>-1)$ prolate shape.

\section{Conclusions}

There are two fault systems with two dominant strikes (North West-South East and North East-South West) and the main conclusions of this research are:

- The direction of the magnetic lineation by using of AMS method shows elongation in North East-South West trend. 


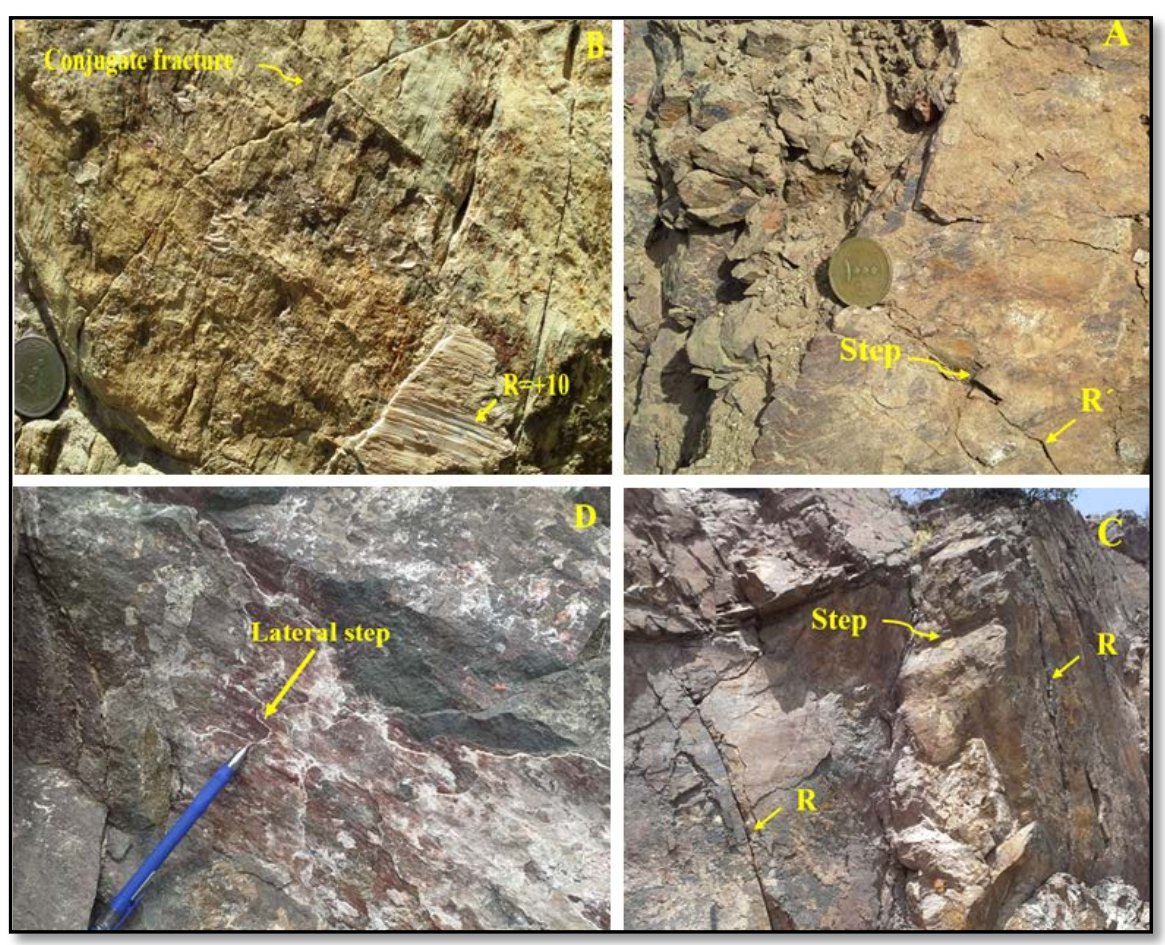

Figure 4. (A) and (C) R and R' fractures along with the fault step, (B) and (D) the amount of the rick angle and scratches line on the surface of the fault.

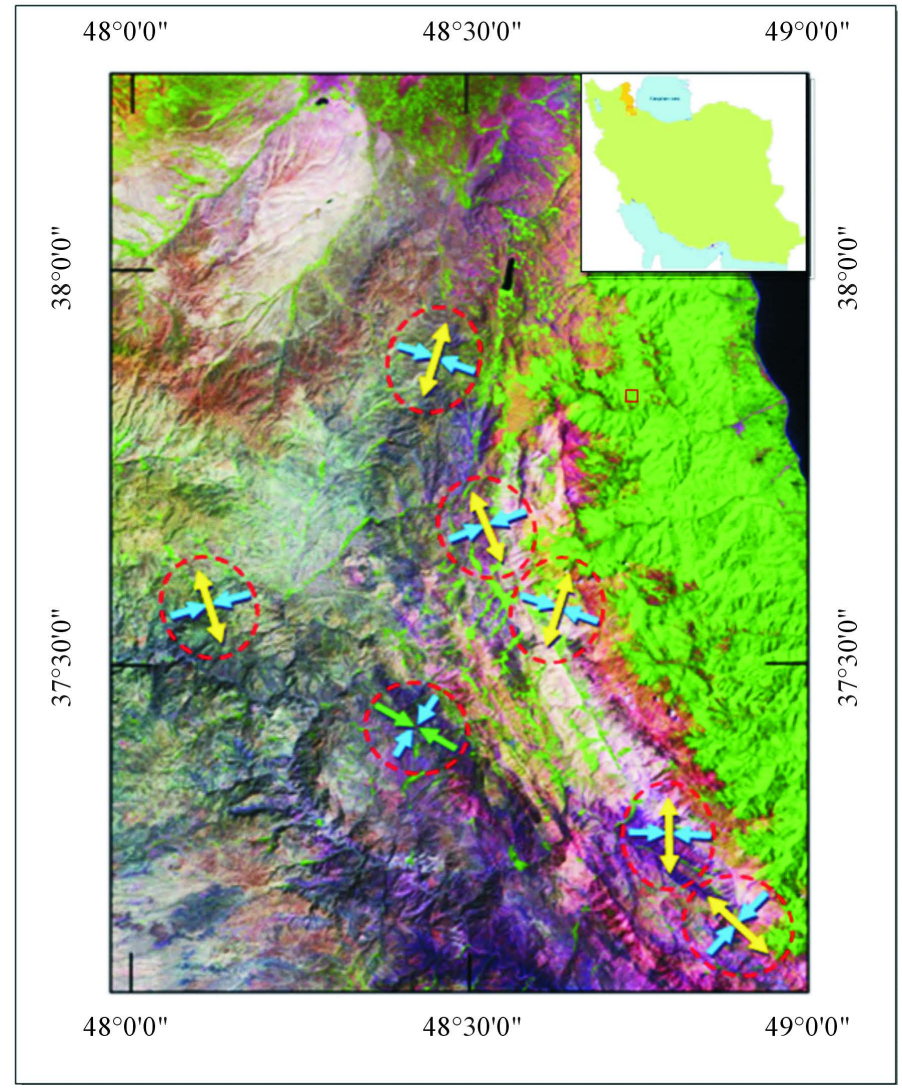

Figure 5. The average position the main tension and elliptical shape in each domain. 


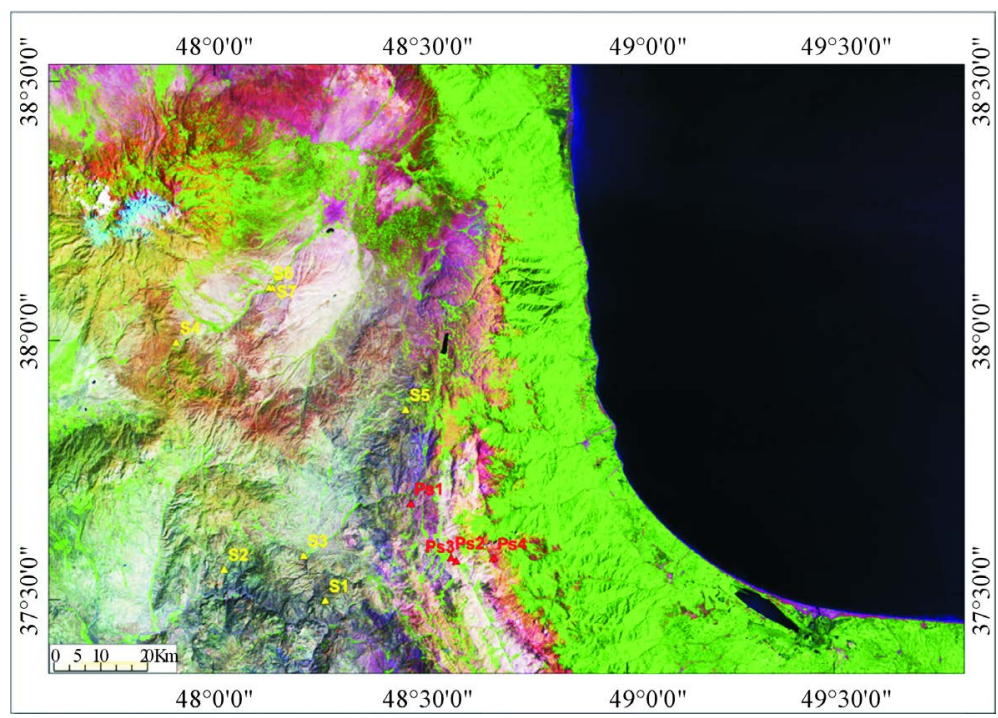

Figure 6. The position of picked up stations for sampling paleomagnetism.

Table 1. Separated phases the position of the main axes; the size of the field shape factor fault numbers related to each phase.

\begin{tabular}{ccccccccc}
\hline \multirow{2}{*}{ Station } & \multirow{2}{*}{ Phases } & \multicolumn{2}{c}{ Sigma 1 } & \multicolumn{2}{c}{ Sigma 3 } & \multirow{2}{*}{$\mathbf{R}$} & \multirow{N}{*}{ N } \\
\cline { 2 - 6 } & & Trend & Plunge & Trend & Plunge & & \\
\hline $\mathbf{1}$ & 1 & 075 & 08 & 344 & 05 & 0.5 & 87 \\
$\mathbf{2}$ & 2 & 248 & 10 & 343 & 10 & 0.6 & 23 \\
$\mathbf{3}$ & 1 & 330 & 00 & 86 & 060 & 0.7 & 15 \\
$\mathbf{4}$ & 1 & 100 & 07 & 191 & 05 & 0.5 & 171 \\
$\mathbf{5}$ & 1 & 076 & 08 & 345 & 05 & 0.5 & 128 \\
\hline
\end{tabular}

Table 2. Geological characteristics, harvested stations, 4 experimental station (PS), and 8 main station (S).

\begin{tabular}{|c|c|c|c|c|}
\hline Station & Position (GPS) & Number samples & Lithology & Relative age \\
\hline $\mathrm{PS}_{1}$ & $\begin{array}{c}\text { N 37²41'16" } \\
\text { E 48² } 28^{\prime} 33.6^{\prime \prime}\end{array}$ & 8 & Eocene volcanic andesite to basalt & Eocene \\
\hline $\mathrm{PS}_{2}$ & $\begin{array}{l}\text { N } 37^{\circ} 34.5^{\prime} 22^{\prime \prime} \\
\text { E } 48^{\circ} 40.6^{\prime} 03^{\prime \prime}\end{array}$ & 8 & Cretaceous volcanic silt & Upper Jurassic \\
\hline $\mathrm{PS}_{3}$ & $\begin{array}{l}\text { N } 37^{\circ} 34^{\prime} 60^{\prime \prime} \\
\text { E } 48^{\circ} 34^{\prime} 36^{\prime \prime}\end{array}$ & 7 & Lime ston & Jurassic \\
\hline $\mathrm{PS}_{4}$ & $\begin{array}{l}\text { N 37034'43" } \\
\text { E 48 } 34^{\circ} 55^{\prime \prime}\end{array}$ & 8 & Lime ston & Jurassic \\
\hline $\mathrm{S}_{1}$ & $\begin{array}{l}\text { N 37³0'11.1" } \\
\text { E 48¹5'52.4" }\end{array}$ & 15 & Andesite & Oligocene \\
\hline $\mathrm{S}_{2}$ & $\begin{array}{l}\text { N } 37^{\circ} 34^{\prime} 03^{\prime \prime} \\
\text { E } 48^{\circ} 00^{\prime} 59^{\prime \prime}\end{array}$ & 15 & Andesite & Oligocene \\
\hline $\mathrm{S}_{3}$ & $\begin{array}{l}\text { N 37³5'27.7" } \\
\text { E 48 } 13^{\circ} 20.9^{\prime \prime}\end{array}$ & 12 & Basalt & Eocene \\
\hline $\mathrm{S}_{4}$ & $\begin{array}{l}\text { N } 37^{\circ} 00^{\prime} 14^{\prime \prime} \\
\text { E } 48^{\circ} 54^{\prime} 27.7^{\prime \prime}\end{array}$ & 8 & Basalt & Quaternary \\
\hline $\mathrm{S}_{5}$ & $\begin{array}{l}\text { N } 37^{\circ} 52^{\prime} 47.6^{\prime \prime} \\
\text { E } 48^{\circ} 28^{\prime} 37.2^{\prime \prime}\end{array}$ & 10 & Andesite & Eocene \\
\hline $\mathrm{S}_{6}$ & $\begin{array}{l}\text { N } 38^{\circ} 06^{\prime} 19.4^{\prime \prime} \\
\text { E } 48^{\circ} 08^{\prime} 04.8^{\prime \prime}\end{array}$ & 17 & Brown marl & Neogene \\
\hline $\mathrm{S}_{7}$ & $\begin{array}{l}\text { N } 37^{\circ} 06^{\prime} 16.9^{\prime \prime} \\
\text { E } 48^{\circ} 54^{\prime} 34.1^{\prime \prime}\end{array}$ & 10 & Red sandstone & Neogene \\
\hline $\mathrm{S}_{8}$ & $\begin{array}{l}\text { N } 37^{\circ} 07^{\prime} 38.2^{\prime \prime} \\
\text { E } 48^{\circ} 09^{\prime} 26.3^{\prime \prime}\end{array}$ & 15 & Red sandstone & Neogene \\
\hline
\end{tabular}




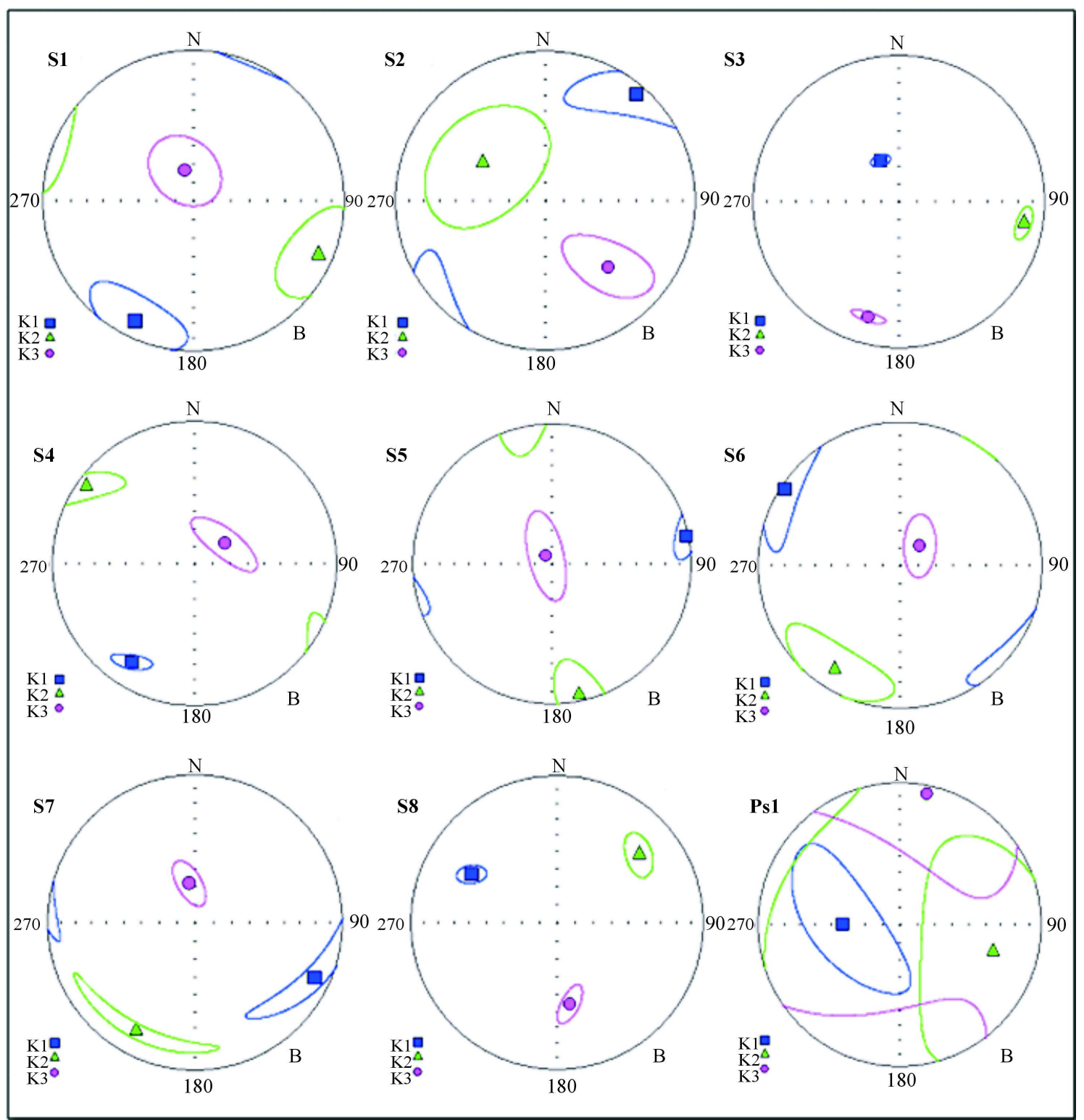

Figure 7. The image of the main axes of the elliptical magnetic susceptibility for three types of magnetic fabric.

Table 3. The measured anisotropy parameters for the study area. Declination and inclination values have separated by comma.

\begin{tabular}{ccccccccc}
\hline Station & $\mathrm{N}$ & $\mathrm{k}_{\mathrm{m}}(\mu \mathrm{SI})$ & $\mathrm{L}$ & $\mathrm{F}$ & $\mathrm{P}_{\mathrm{J}}$ & $\mathrm{T}_{\mathrm{J}}$ & Dec, Inc. $\left(\mathrm{K}_{\min }\right)$ & Dec, Inc. $\left(\mathrm{K}_{\max }\right)$ \\
\hline PS1 & 8 & $3.83 \mathrm{E}$ & $1.001(0.001)$ & $1.004(0.002)$ & $1.004(0.030)$ & $-0.169(0.3380)$ & 12.7 & 271.56 \\
S1 & 14 & $9.69 \mathrm{E}$ & $1.004(0.002)$ & $1.007(0.004)$ & $1.011(0.004)$ & $0.306(0.388)$ & 322.71 & 211.67 \\
S2 & 15 & $4.65 \mathrm{E}$ & $1.005(0.004)$ & $1.004(0.005)$ & $1.009(0.466)$ & $-0.056(0.446)$ & 136.39 & 40.8 \\
S3 & 12 & $5.52 \mathrm{E}$ & $1.006(0.001)$ & $1.005(0.002)$ & $1.011(0.002)$ & $-0.139(0.163)$ & 195.20 & 330.65 \\
S4 & 9 & $2.25 \mathrm{E}$ & $1.003(0.002)$ & $1.003(0.001)$ & $1.007(0.002)$ & $-0.035(0.267)$ & 56.72 & 211.16 \\
S5 & 9 & $2.43 \mathrm{E}$ & $1.008(0.001)$ & $1.003(0.003)$ & $1.012(0.002)$ & $-0.164(0.234)$ & 323.83 & 78.2 \\
S6 & 13 & $6.4 \mathrm{E}$ & $1.007(0.004)$ & $1.055(0.013)$ & $1.045(0.017)$ & $0.652(0.122)$ & 44.74 & 303.3 \\
S7 & 9 & $1.23 \mathrm{E}$ & $1.008(0.002)$ & $1.052(0.026)$ & $1.066(0.029)$ & $0.720(0.129)$ & 301.68 & 114.12 \\
S8 & 15 & $9.27 \mathrm{E}$ & $1.002(0.009)$ & $1.043(0.016)$ & $1.065(0.022)$ & $0.349(0.221)$ & 171.43 & 299.33 \\
\hline
\end{tabular}


- The trend of magnetic lineation is the same with the direction tension, based on the results of both paleostress and paleomagnetism methods.

- The value of $\mathrm{R}$ in the paleostress method is variable from 0.5 to 1 and with the implementation of the [112] diagram field shape is obtained to be prolate.

- The value of TJ in the anisotropy of magnetic susceptibility (AMS) is variable between 0 and -1 and with the implementation of [113] and [114] field shape is prolate.

- The results of both paleostress and anisotropy of magnetic susceptibility (AMS) methods for field shape of Strain ellipsoid are the same.

\section{Acknowledgements}

This study was conducted as a part of Ph.D. dissertation by Science and Research Branch, Islamic Azad University, Tehran, Iran. Authors have got special thanks to Dr. H. Alimohammadian from Geologic Survey of Iran to his support.

\section{References}

[1] Arian, M. (2013) Physiographic-Tectonic Zoning of Iran’s Sedimentary Basins. Open Journal of Geology, 3, 169-177. http://dx.doi.org/10.4236/ojg.2013.33020

[2] Qorashi, M. and Arian, M. (2011) Tectonics of Iran. Geologic Survey of Iran, Tehran, 336 p.

[3] Arian, M. (2011) Basement Tectonics and Geology of Iran. Asar Nafis Press, Qum, 300 p.

[4] Arian, M. (2011) A Preface on Salt Diapirism of Iran. Asar Nafis Press, Qum, 309 p.

[5] Arian, M. and Noroozpour, H. (2015) The Biggest Salt-Tongue Canopy of Central Iran. Open Journal of Geology, 5, 55-60. http://dx.doi.org/10.4236/ojg.2015.52005

[6] Asadian, F., Pourkermani, M. and Arian, M. (2007) Tectonic Geomorphology of Salt Structures in the GarmsarLasjerd Area. Geographical Research, 39, 75-84.

[7] Pourkermani, M. and Arian, M. (1997) Salt Domes of Central Iran. Journal of Humanities, 3, $29-41$.

[8] Arian, M. (2012) Salt Diapirism and Tectonics. 2nd Edition, Asar Nafis Press, Qum, 319 p.

[9] Arian, M. and Noroozpour, H. (2015) Tectonic Geomorphology of Iran's Salt Structures. Open Journal of Geology, 5, 61-72. http://dx.doi.org/10.4236/ojg.2015.52006

[10] Asadian, F. and Arian, M. (2009) Identification of Diapiric Provinces of Central Iran through Geological and Geographical Analysis. International Journal of Agriculture Environment \& Biotechnology, 2, 3443-3451.

[11] Arian, M. (2012) Clustering of Diapiric Provinces in the Central Iran Basin. Carbonates and Evaporites, 27, 9-18. http://dx.doi.org/10.1007/s13146-011-0079-9

[12] Pourkermani, M. and Arian, M. (1998) Tectonic Geomorphology of Salt Domes in West of Zanjan Province, Iran. Geographical Research, 47, 44-53.

[13] Arian, M. and Feizi, F. (2010) The Significance of Faulting on the Surficial Spreading of Evaporitic Deposits in the Varamin-Semnan Area. Journal of Earth and Resources, 3, 1-20.

[14] Feizi, F., Arian, M. and Arian, A. (2015) Mud Diapirism on the Makran, Iran: Case Study on the Napag Mud Volcano. Open Journal of Geology, 5, 300-308. http://dx.doi.org/10.4236/ojg.2015.55027

[15] Arian, M. and Sistanipour, A. (2015) Mud Diapirism on the Gorgan, North Iran. Open Journal of Geology, 5, $442-450$.

[16] Arian, M. and Khodabakhshnezhad, A. (2015) Sedimentary Environments Can Be Changed by Geotechnology (Case Study: A Morphotectonic Idea for Design of Extensive Artificial Bay on the Iranian Plateau). International Journal of Geosciences, 6, 487-496. http://dx.doi.org/10.4236/ijg.2015.65039

[17] Arian, M. (2011) Middle East Tectonics. AsarNafis Press, Qum, 236 p.

[18] Arian, M. (2010) Applied Seismotectonics. Farazamin Press, Tehran, 304 p.

[19] Arian, M. and Maleki, R. (2008) Neotectonics. Farazamin Research Center, Tehran, 150.

[20] Pourkermani, M. and Arian, M. (1998) Seismicity of Iran. Shahid Beheshti University Press, Tehran, 212.

[21] Pourkermani, M. and Arian, M. (1997) Seismotectonics. DezAb Consulting Engineers Company Press, Tehran, 270.

[22] Arian, M. and Aram, Z. (2014) Relative Tectonic Activity Classification in the Kermanshah Area, Western Iran. Solid Earth, 5, 1277-1291. http://dx.doi.org/10.5194/se-5-1277-2014

[23] Mashal, M., PourKermani, M., Charchi, A., Almasian, M. and Arian, M. (2013) Pattern of Structural Geology Under- 
ground in Eastern of North Dezfol Embayment. Advances in Environmental Biology, 7, 260-268.

[24] Pazhoohan, M., Arian, M., Ghorashi, M. and Khosrotehrani, K. (2014) A Study of Drainage Pattern Responses to Active Tectonics in Tadvan Region, SW Iran. Geodynamics, 1, 36-41.

[25] Rahimi, N. and Arian, M. (2014) Tectonic Geomorphplogy of Kangavar-Sosangerd Region, West Iran. Advances in Environmental Biology, 8, 119-124.

[26] Arian, M. and Hashemi, A. (2008) Seismotectonic Zoning in the Zagros. Journal of Sciences, 18, 63-76.

[27] Arian, M., Ahmadnia, A., Qorashi, M. and Pourkermani, M. (2002) Structural Analysis of Mengharak Transcurrent Fault System in Zagros, Iran. Special Geo 2002 Conference Issue Geoarabia, 7, 209-210.

[28] Arian, M., Qorashi, M., Pourkermani, M. and Ahmadnia, A. (2003) Fractal Analysis of Mengharak Transcurrent Fault System in Zagros, Iran. Abstracts of 4th International Conference on Seismology and Earthquake Engineering, Tehran, 12-14 May 2003, 23.

[29] Baharvand, S., Pourkermani, M., Ajalloian, R., Arian, M. and Nouryazdan, A.R. (2010) Seymareh Landslide and Its Role in Environmental and Geomorphologic Changes of the Pole-Dokhtar Area. Journal of the Earth, 4, 13-24.

[30] Abdideh, M., Qorashi, M., Rangzan, K. and Arian, M. (2011) Assessment of Relative Active Tectonics Using Morphometric Analysis, Case Study of Dez River (Southwestern, Iran). Geosciences, 20, 33-46.

[31] Arian, M., Qorashi, M., Pourkermani, M. and Ahmadnia, A. (2006) The Structural Significance Kareh Bas Transcurrent Fault System in the Zagros Fold and Thrust Belt. Geosciences, 15, 126-133.

[32] Arian, M. and Noroozpour, H. (2015) Seismic Activity and Fractal Geometry of Kareh Bas Fault System in Zagros, South of Iran. Open Journal of Geology, 5, 291-299. http://dx.doi.org/10.4236/ojg.2015.55026

[33] Ehsani, J. and Arian, M. (2015) Quantitative Analysis of Relative Tectonic Activity in the Jarahi-Hendijan Basin Area, Zagros Iran. Geosciences Journal, 19, 1-15. http://dx.doi.org/10.1007/s12303-015-0016-3

[34] Omidali, M., Arian, M. and Sorbi, A. (2015) Neotectonics of Boroujerd Area, SW Iran by Index of Active Tectonics. Open Journal of Geology, 5, 309-324.

[35] Chegini, A., Sorbi, A. and Arian, M. (2015) Active Tectonics of Hamedan Area, SW Iran by Index of Active Tectonics. International Journal of Geology, 4, 108-118.

[36] Maleki, Z., Arian, M., Solgi, A. and Ganjavian, M.A. (2014) The Elements of Fold Style Analysis in the Khaftar Anticline, Zagros, Iran. Open Journal of Geology, 4, 79-92. http://dx.doi.org/10.4236/ojg.2014.43008

[37] Maleki, Z., Arian, M. and Solgi, A. (2014) Structural Style and Hydrocarbon Trap of Karbasi Anticline, in the Interior Fars Region, Zagros, Iran. Solid Earth Discussions, 6, 2143-2167. http://dx.doi.org/10.5194/sed-6-2143-2014

[38] Ehsani, J., Arian, M. and Ghorashi, M. (2015) Geomorphic Signatures of Active Tectonics in the Jarahi-Hendijan Drainage Basin in the south West Iran. Geosciences, 24, 211-218.

[39] Khodabakhshnezhad, A., Pourkermani, M., Arian, M., Matkan, A.A. and Charchi, A. (2015) Active Tectonics of Great Karoun River Basin. Geosciences, 24, 13-28.

[40] Maleki, Z., Arian, M., Solgi, A. and Ganjavian, M.A. (2015) Elements of Fold Style Analysis in the Karbasi Anticline, Interior Fars Region, Zagros. Geosciences, 24, 293-302.

[41] Baratpour, F., Arian, M. and Solgi, A. (2015) Geometric Analysis of Tukak and Kamarun Anticlines on Izeh Zone, Zagros. Geosciences, 24, 191-200.

[42] Gholamhosein Fard, N., Sorbi, A. and Arian, M. (2015) Active Tectonics of Kangavar Area, West Iran. Open Journal of Geology, 5, 422-441.

[43] Maleki, Z., Arian, M. and Solgi, A. (2015) Folding Pattern in the Fars Province, Zagros Folded Belt: Case Study on the Karbasi and Khaftar Anticlines, Interior Fars, Iran. Solid Earth Discuss, 7, 2347-2379.

[44] Alladin, Y., Talebian, M., Arian, M. and Ahmadi, M.M. (2015) Geotechnical Investigation and Seismic Zonation of Alluvial Deposits in Western Tehran. Geosciences, 24, 333-342.

[45] Taherkhani, B., Nazari, H., Pourkermani, M. and Arian, M. (2015) Geometry and Recent Kinematics of the North Qazvin Fault: Morphotectonic Approach. Geosciences, 24, 29-38.

[46] Manuchehri, H., Arian, M., Ghorashi, M., Solgi, M. and Sorbi, A. (2015) Geomorphic Signatures of Active Tectonics in the Chalus Drainage Basin in the Alborz, Iran. Geosciences, 24, 273-280.

[47] Noroozpour, H., Arian, M. and Sorbi, A. (2015) Fault Movement Potentials in the Tehran-Semnan Region (North Iran). Open Journal of Geology, 5, 281-290. http://dx.doi.org/10.4236/ojg.2015.55025

[48] Arian, M., Maleki, Z. and Noroozpour, H. (2011) Cenozoic Diastrophism and Deformational Events in the East Central Alborz. Journal of Basic and Applied Scientific Research, 1, 2394-2400.

[49] Feizi, F., Arian, A. and Rahmani, R. (2007) Seismotectonic Zoning in the Eastern Part of the Central Alborz. Journal 
of Sciences, 17, 151-164.

[50] Khavari, R., Arian, M. and Ghorashi, M. (2009) Neotectonics of the South Central Alborz Drainage Basin, in NW Tehran, N Iran. Journal of Applied Sciences, 9, 4115-4126. http://dx.doi.org/10.3923/jas.2009.4115.4126

[51] Arian, M. and Bagha, N. (2012) Active Tectonics of Tehran Area, Iran. Journal of Basic and Applied Scientific Research, 2, 3805-3819.

[52] Bagha, N., Arian, M., Ghorashi, M., Pourkermani, M., El Hamdouni, R. and Solgi, A. (2014) Evaluation of Relative Tectonic Activity in the Tehran Basin, Central Alborz, Northern Iran. Geomorphology, 213, 66-87. http://dx.doi.org/10.1016/j.geomorph.2013.12.041

[53] Khosroshahizadeh, S., Pourkermani, M., Almasiyan, M., Arian, M. and Khakzad, A. (2015) Evaluation of Structural Patterns and Related Alteration and Mineralization Zones by Using ASAR-ASTER Imagery in Siyahrood Area (East Azarbaijan-NW Iran). Open Journal of Geology, 5, 589-610. http://dx.doi.org/10.4236/ojg.2015.59053

[54] Arian, M., Bagha, N., Khavari, R. and Noroozpour, H. (2012) Seismic Sources and Neo-Tectonics of Tehran Area (North Iran). Indian Journal of Science and Technology, 5, 2379-2383.

[55] Moghimi, H., Arian, M. and Sorbi, A. (2015) Fault Movement Potential of Marzanabad Area, North Alborz, Iran. Open Journal of Geology, 5, 126-135. http://dx.doi.org/10.4236/ojg.2015.53012

[56] Arian, M. and Pourkermani, M. (2004) Tectonic Elements of South Flank in the East-Central Alborz Mountain. Journal of Sciences (Teacher Training University), 4, 359-368.

[57] Arian, M. and Qorashi, M. (2006) The Movement Potential Evaluation of the Major Quaternary Faults in Alborz- Central Iran Border Zone, from the East of Tehran to the East of Semnan. Journal of Geosciences (Geological Survey of Iran), 15, 184-188.

[58] Poroohan, N., Pourkermani, M. and Arian, M. (2013) An Assessment of Relationship in F-Parameter and Paleostress Fields in Heterogeneous Lithologies: Roudbar Area (Northwest of Iran). Australian Journal of Basic \& Applied Sciences, 7, 933-942.

[59] Poroohan, N., Poukermani, M. and Arian, M. (2009) An Assessment on Correlations of Seismotectonic Parameters Preceding and Following Roudbar-Manjil Earthquake (Gilan, North of Iran). Australian Journal of Basic \& Applied Sciences, 3, 2643-2652.

[60] Farrokhnia, A.R., Pirasteh, S., Pourkermani, M. and Arian, M. (2011) Geo-Information Technology for Mass Wasting Hazard Zonation: Central-West Alborz-Iran. Disaster Advances, 4, 24-33.

[61] Khavari, R., Ghorashi, M. and Arian, M. (2009) Assessment of Relative Active Tectonics, South Central Alborz (North Iran). EGU General Assembly Conference Abstracts, 11, 1137.

[62] Sorbi, A., Arian, M. and Pourkermani, M. (2009) The Movement Potential Evaluation of the Major Quaternary Faults in Tehran Quadrangle. Journal of the Earth, 19, 176-182.

[63] Feizi, F. and Arian, M. (2006) The Classification of Thrust Fronts in the Alborz-Central Iran Border Zone from the East of Varamin to the East of Semnan. Journal of Sciences, 16, 75-87.

[64] Arian, M. and Feizi, F. (2005) Application of Geomorphic Indices to the Assessment of Relative Tectonic Activity Levels in the Alborz-Central Iran Border Zone. Journal of Science, 15, 378-403.

[65] Arian, M. and Pourkermani, M. (2004) Structural Significance of North Semnan and Attary Faults in Alborz-Central Iran Border Zone. Journal of Science, 14, 4551-4569.

[66] Arian, M. and Pourkermani, M. (2005) Cenozoic Diastrophism and Deformational Events in the Southern Flank of Central-East Alborz. Journal of Faculty Earth Sciences, 10, 43-51.

[67] Arian, M., Pourkermani, M., Qorashi, M. and Ghasemi, M.R. (2003) North Semnan Fault System and Its Role on Basin Division. 8th Symposium of Geological Society of Iran, Shahrood University of Technology, 4-6 September 2003, 11-17.

[68] Pourkermani, M. and Arian, M. (2001) Structural Geomorphology of Northeastern Kurdistan. Journal of Humanities, 7, 37-48.

[69] Mardani, Z., Ghorashi, M. and Arian, M. (2011) Geomorphic Signatures of Active Tectonics in the Talaghan Rud, Shah Rud and Sefidrud Drainage Basins in Central Alborz, N Iran. Geosciences, 20, 159-166.

[70] Sorbi, A., Arian, M. and Pourkermani, M. (2011) The Application of Geomorphic Indices to the Assessment of Relative Tectonic Activity Levels in Tehran Quadrangle. Journal of the Earth, 6, 1-9.

[71] Khavari, R., Ghorashi, M., Arian, M. and Khosrotehrani, K. (2010) Geomorphic Signatures of Active Tectonics in the Karaj Drainage Basin in South Central Alborz, N Iran. Geosciences, 19, 67-74.

[72] Mousavi, E.J. and Arian, M. (2015) Tectonic Geomorphology of Atrak River, NE Iran. Open Journal of Geology, 5, 106-114. http://dx.doi.org/10.4236/ojg.2015.53010 
[73] Nouri, R., Jafari, M.R., Arian, M., Feizi, F. and Afzal, P. (2013) Correlation between Cu Mineralization and Major Faults Using Multifractal Modelling in the Tarom Area (NW Iran). Geologica Carpathica, 64, 409-416. http://dx.doi.org/10.2478/geoca-2013-0028

[74] Nouri, R., Jafari, M.R., Arian, M., Feizi, F. and Afzal, P. (2013) Prospection for Copper Mineralization with Contribution of Remote Sensing, Geochemical and Mineralographical Data in Abhar 1:100,000 Sheet, NW Iran. Archives of Mining Sciences, 58, 1071-1084. http://dx.doi.org/10.2478/amsc-2013-0074

[75] Nouri, R., Afzal, P., Arian, M., Jafari, M. and Feizi, F. (2013) Reconnaissance of Copper and Gold Mineralization Using Analytical Hierarchy Process in the Rudbar 1:100,000 Map Sheet, Northwest Iran. Journal of Mining and Metallurgy, 49, 9-19.

[76] Farrokhnia, A.R., Pirasteh, S., Pradhan, B., Pourkermani, M. and Arian, M. (2011) A Recent Scenario of Mass Wasting and Its Impact on the Transportation in Alborz Mountains, Iran Using Geo-Information Technology. Arabian Journal of Geosciences, 4, 1337-1349. http://dx.doi.org/10.1007/s12517-010-0238-7

[77] Arian, M. and Nouri, R. (2015) Lineament Tectonics and Mineralization in Tarom Area, North Iran. Open Journal of Geology, 5, 115-124. http://dx.doi.org/10.4236/ojg.2015.53011

[78] Feizi, F. and Arian, M. (2011) The Role of Structural Controllers in Geneses of Copper Deposits in 1:50,000 Map of Saiin Qaleh. Journal of Sciences, 21, 1-10.

[79] Arian, M., Qorashi, M. and Ahmadnia, A. (2003) Analysis of Behbahan Shear Zone. Iranian journal of Geology, 1, 14.

[80] Bahiraee, S., Arian, M., Qorashi, M. and Solgi, M. (2015) The Movement Potential Evaluation of the Mosha Fault (the West of Firoozkuh to the Shahrestanak). Geosciences, 24, 123-126.

[81] Bagha, N., Ghorashi, M., Arian, M., Pourkermani, M. and Solgi, A. (2015) Neotectonic Analysis of Mosha-North Tehran Fault Zone, Based on Morphotectonic Features, Central Alborz, Northern Iran. Geosciences, 24, 41-52.

[82] Mosavi, E. and Arian, M. (2015) Neotectonics of KashafRud River, NE Iran by Modified Index of Active Tectonics (MIAT). International Journal of Geosciences, 6, 776-794. http://dx.doi.org/10.4236/ijg.2015.67063

[83] Nouri, R. and Arian, M. (2015) Structural Control on the Distribution of Hydrothermal Alteration Zones and Mineralization in Dastjerdeh Area Based on Remote Sensing Data, NW Iran. Bulletin of the Georgian National Academy of Sciences, 9, 79-86.

[84] Sistanipour, A. and Arian, M. (2015) Geometric Analysis of Davaran Fault System, Central Iran. Open Journal of Geology, 5, 458-469.

[85] Nazemi, M., Ghorashi, M., Ghassemi, M.R. and Arian, M. (2015) Morphotectonics Features of Alluvial Fans Associated with Active Tectonics (Shotori Mountains, East of Tabas-Central Iran). Geosciences, 24, 91-100.

[86] Alizadeh, H. and Arian, M. (2015) Rule of Structural Factors in Formation of Porphyry Copper Deposits in South Western Part of Kerman Area, Iran. Open Journal of Geology, 5, 489-498.

[87] Mosavi, E.J. and Arian, M. (2015) Neotectonics of Tabas Area, Central Iran by Index of Active Tectonics (IAT). Open Journal of Geology, 5, 209-223. http://dx.doi.org/10.4236/ojg.2015.54019

[88] Daryani, N.J., Arian, M. and Omran, N.R. (2015) Tectonics and Mineralization of Copper in the Ardestan-Kahang Area, Central Iran by Remote Sensing. Open Journal of Geology, 5, 188-196. http://dx.doi.org/10.4236/ojg.2015.54017

[89] Arian, M. and Pourkermani, M. (2001) Rivers Morphology and Active Tectonic (Reviewing the Current Status of Ghezel Ozon River in the Province of Zanjan). 5th Conference of Geological Society of Iran, Tehran, 28-30 August 2001, 556.

[90] Eshghi, Z., Arian, M. and Pourkermani, M. (2012) Structural INVESTIGATION on the Lak Mining Area (Bueen Zahra) Based on Remote Sensing, Used for Its Mineralization. Journal of the Earth, 6, 145-155.

[91] Arian, M., Toudeshki, V.H. and Noroozpour, H. (2011) Active Tectonics of Qezel Ozan River Basin, NW Iran. Journal of Applied Environmental and Biological Sciences, 1, 291-295.

[92] Alizadeh, H., Arian, M., Lotfi, M., Ghorashi, M. and Ghorbani, M. (2015) Determination of Porphyry Copper Deposit Locations Using Photo Lineament Factor in Northern Parts of the Dehaj-Sardoiyeh Belt. Geosciences, 24, $247-252$.

[93] Toudeshki, V.H., Pourkermani, M., Arian, M. and Khosrotehrani, K.H. (2011) Influence of Structures on the Ghezel Ozan River. Geosciences, 21, 55-60.

[94] Toudeshki, V.H. and Arian, M. (2011) Morphotectonic Analysis in the Ghezel Ozan River Basin, NW Iran. Journal of Geography and Geology, 3, 258-260.

[95] Arian, M. (2015) Seismotectonic-Geologic Hazards Zoning of Iran. Earth Sciences Research Journal, 19, 7-13. http://dx.doi.org/10.15446/esrj.v19n1.40664

[96] Arian, M., Pourkermani, M., Sistanipour, A. and Noroozpour, H. (2011) Kinematic Significance of Fold- and Fault- 
Related Fracture Systems in the Rafsanjan’s Northeast Highlands (Central Iran). Journal of Basic and Applied Scientific Research, 1, 3398-3406.

[97] Arian, M., Pourkermani, M., Sistanipour, A. and Noroozpour, H. (2011) Seismicity and Fault Segmentation of BafqBaghin Fault System (Central Iran). Journal of Applied Environmental and Biological Sciences, 1, 382-396.

[98] Mosavi, E.J., Arian, M., Ghorashi, M and Nazemi, M. (2012) Measurments of Geomorphic Indices in Tabas Area. Journal of the Earth, 7, 213-225.

[99] Arian, M. (2010) Earthquake-Fault Hazard Investigations in the Kerman Quadrangle. Journal of Sciences, 19, $176-182$.

[100] Manafi, M., Arian, M., Raeesi, S. and Solgi, A. (2013) Tethys Subduction History in Caucasus Region. Open Journal of Geology, 3, 222-232. http://dx.doi.org/10.4236/ojg.2013.33026

[101] Angelier, J. (1994) Fault Slip Analysis and Paleostress Reconstruction. In: Hancock, P.L., Ed., Continental Deformation, Pergamon Press, Oxford, 53-100.

[102] Larrasoaña, J.C., Pueyo, E.L. and Parés, J.M. (2004) An Integrated AMS, Structural, Palaeo-and Rock-Magnetic Study of the Eocene Marine Marls from the Jaca-Pamplona Basin (Pyrenees, N Spain); New Insights into the Timing of Magnetic Fabric Acquisition in Weakly Deformed Mudrocks. Geological Society of London, 238, 127-144. http://dx.doi.org/10.1144/GSL.SP.2004.238.01.10

[103] Lee, T.Q., Kissel, C., Laj, C., Horng, C. and Lue, Y. (1990) Magnetic Fabric Analysis of the Plio-Pleistocene Sedimentary Formations of the Coastal Range of Taiwan. Earthand Planetary Science Letters, 98, 23-32. http://dx.doi.org/10.1016/0012-821X(90)90085-C

[104] Lowrie, W. and Hirt, A.M. (1987) Anisotropy of Magnetic Susceptibility in the Scaglia Rossa Pelagic Limestone. Earth and Planetary Science Letters, 55, 181-189.

[105] Luneburg, C.M., Lampert, S.A., Lebit, H.D., Hirt, A.M., Casey, M. and Lowrie, W. (1999) Magnetic Anisotropy, Rock Fabrics and Finite Strain in Deformed Sediments of SW Sardinia (Italy). Tectonophysics, 307, 51-74. http://dx.doi.org/10.1016/S0040-1951(99)00118-3

[106] Mattei, M., Funiciello, R., and Kissel, C. (1995) Paleomagnetic and Structural Evidence of Neogene Block Rotation in the Central Apennines, Italy. Journal Geophysical Research, 100, 17863-17883. http://dx.doi.org/10.1029/95JB00864

[107] Baas, J.H., Hailwood, E.A., McCaffrey, W.D., Kay, M. and Jones, R. (2007) Directional Petrological Characterisation of Deep-Marine Sandstones Using Grain Fabric and Permeability Anisotropy: Methodologies, Theory, Application and Suggestions for Integration. Earth-Science Reviews, 82, 101-142. http://dx.doi.org/10.1016/j.earscirev.2007.02.003

[108] Borradaile, G.J. and Tarling, D.H. (1981) The Influence of Deformation Mechanisms on Magnetic Fabrics in Weakly Deformed Rocks. Tectonophysics, 77, 151-168. http://dx.doi.org/10.1016/0040-1951(81)90165-7

[109] Borradaile, G.J. and Henry, B. (1997) Tectonic Applications of Magnetic Susceptibility and Its Anisotropy. Earth Science Reviews, 42, 49-93. http://dx.doi.org/10.1016/S0012-8252(96)00044-X

[110] Butler, R. F. (2004) Paleomagnetism: Magnetic Domains to Geologic Terranes. Electronic Edition, London, 238 p.

[111] Cifelli, F., Rossetti, F., Mattei, M., Hirt, A.M., Funiciello, R. and Tortorici, L. (2004) An AMS, Structural and Paleomagnetic Study of Quaternary Deformation in Eastern Sicily. Journal of Structural Geology, 26, 29-46. http://dx.doi.org/10.1016/S0191-8141(03)00092-0

[112] Cifelli, F., Mattei, M., Chadima, M., Hirt, A. and Hansen, A. (2005) The Origin of Tectonic Lineation in Extensional Basins: Combined Neutron Texture and Magnetic Analyses on Undeformed Clays. Earth and Planetary Science Letters, 235, 62-78. http://dx.doi.org/10.1016/j.epsl.2005.02.042

[113] Flinn, D. (1965) On the Symmetry Principle and the Deformation Ellipsoid. Geological Magazine, 102, 36-45. http://dx.doi.org/10.1017/s0016756800053851

[114] Hrouda, F. (1982) Magnetic Anisotropy of Rocks and Its Application in Geology and Geophysics. Surveys in Geophysics, 5, 37-82. http://dx.doi.org/10.1007/BF01450244 